\title{
Across the Manager's desk
}

On-going end-of-the-year work at Head Office includes a careful check of members by individual name and address, and by Section. The check by Sections is necessitated by the fact that Section dues collected by Head Office are turned over to the various treasurers at this time. An alphabetical list is forwarded at the time of transfer of the funds so that Treasurers or Secretaries may cross check their own membership lists with their card file. This is the only time that a complete double check between Head Office membership card files and Section membership card files may be made without running additional lists. Of course, additional lists can be run at other times of the year for the convenience of Secretaries or for special reasons, but this is time consuming and redundant if the necessary checking is done when the Section Dues List is forwarded.

Head Office double checks these lists against the addressograph plates, through the list itself, through the individual card list which contains total membership in alphabetical order at Head Office, through the individual file envelope if necessary, and by any change of address or of membership class throughout the year.

The Section Dues List serves an additional purpose in that dues delinquent members are noted for both Head Office and Sections at this time. Thus Sections are notified before the names are struck from the rolls for non-payment of dues. This allows the Section Council, or anyone they have appointed for the task, to contact members whose dues are not paid and thus preclude the necessity of strikeoff and reinstatement.

There have been several requests from Sections and individuals this winter for information on handling members who are retiring from full time work. The proper method of applying for retired status is through the Section Council. The applicant should apply in writing to the Chairman or Secretary of the Section to which he belongs providing pertinent information, such as the date of retirement and the number of years which the applicant has been a member.
The application is considered by the Section Council and, if approved, should be forwarded to Head Office. Here the application will be processed if approved and all records changed to indicate the member now holds retired status. The applicant is then informed of his rights and the Section is notified of the change of status. The rights of a member holding retirement status include all those rights to which he was entitled before gaining retired status (depending on which classification he held prior to retirement) plus the fact that he obtains all these rights (with the exception of one) without payment of annual dues. The one exception is receipt of The Forestry Chronicle. If the retired member wishes to receive The Forestry Chronicle he must pay the going subscription rate for the magazine ( $\$ 10.00$ annually in 1974$)$.

A member, according to the By-laws, should have been a member for at least fifteen (15) years before he is eligible for retired status. However, the Section Council has the right to recommend retired status for a member of less than fifteen (15) years good standing if they feel in their collective wisdom that such action is warranted.

The actual By-laws pertinent to retired status for a member of the Canadian Institute of Forestry reads as follows:

\subsection{Retirement}

4.4.1. Application for retired status. An Active or Affiliate Member who has been a member of the Institute for fifteen or more years and who retires from such activity as was the basis of his qualification for membership may apply to his Section Council for a continuation in that class of membership without payment of dues. 'Retirement' shall be interpreted as retirement from full-time employment with a substantial reduction in income.

4.4.2. Examination. The section Council shall examine an application for Retired status and may recommend acceptance by the Executive Committee. Under special circumstances the minimum requirement of fifteen years previous membership may be waived if Council so advises.

4.4.3. Subscription to The Forestry Chronicle. Retired members may receive THE FORESTRY CHRONICLE on payment of such annual charge as may from time to time be recommended by the Board of Directors for approval by the membership.

\section{W. Donald Bennett}

Less than two years after his retirement as Head of the Logging Section, Pulp and Paper Research Institute of Canada, Don Bennett died on 26 April 1973 as the result of an accidental fall in his Toronto home.

Don Bennett's career included an exceptionally broad range of experience in Canadian forestry and logging. After receiving his B.Sc.F. degree from the University of Toronto in 1932, Mr. Ben- nett worked briefly for Ontario Hydro and Davey Tree Surgeons. From 1933 to 1942 he was involved with logging operations of Spruce Falls Power \& Paper Co. Ltd., where he reached the level of individual superintendent and gained a lifetime membership in the Smokey Line Club.

Following three years of war production work with Defence Industries, Ltd., Don Bennett joined the Woodlands Section,
CPPA, as assistant manager. Between 1952 and 1955 he was a member of the sales staff of Timberland Machines and in the motel business in Muskoka, Ontario.

In 1955 he joined the Pulp and Paper Research Institute as forester and logging engineer. During the next 16 years he wrote more than a score of research reports on varied subjects. Among them were reviews of the stateof-the-art in flumes and cable- 
ways which were standard works, and the notable Logging Atlas of Eastern Canada. His reports are models of lucid technical writing, and he had the gift of surgical precision in improving the writings of his colleagues.

A member of the CIF since graduation, Don Bennett was active in Institute activities and served as chairman of the Champlain Section from 1963 to 1965. He contributed a history of that section to K. G. Fensom's historical volume Expanding Forestry Horizons.

\section{Alva Sherwin Bray}

At the time of his death $\mathrm{Al}$ Bray was Chairman of the Ontario Ministry of the Environment Solid Waste Task Force. He had previously retired as Deputy Minister from the Department of Industry and Tourism on 31 October 1972.

Al was born in Midland in 1907, where he received his early edu- cation. He had a background in the woods industry and his father ran a planning mill in the Midland area for a number of years. He attended the University of Toronto where he graduated with a Bachelor of Science Degree in Forestry in 1931.

Following graduation, he was employed by the Abitibi Power and Paper Co. and subsequently joined the Department of Lands and Forests in 1943 as District Forester in the Cochrane-Kapuskasing area. Al moved to Toronto and served as Chief of the Lands Branch from 1954 until 1958. He then moved from Toronto to the Lakehead in 1958 as one of the two Regional Directors in the Department where he remained until 1964. In 1964 he joined the Department of Travel and Publicity as Deputy Minister and worked in that capacity until his retirement in 1972.

Al was one of the twelve char- ter members of the Ontario Professional Foresters Association when it was formed in 1957, and he served as a member of the first council during the initial term. He was also a member of the Canadian Institute of Forestry for many years.

During his long career with the Government, Al was well known and widely respected by his many associates both within the Civil Service and in industry where he was active for so many years. He will be sadly missed by everyone who had the opportunity of meeting him.

\section{CIF committees}

Bob Burgar is the new chairman of the Land Use Planning Committee, replacing Norm Kissick. Graham Powell, of UNB's Faculty of Forestry has agreed to serve on the Board of Examiners, to replace Don Munro of UBC.

\section{Section news}

\section{Algonquin College and other matters}

Bill Collins reported to the Section on the activities of the Pembroke Campus of Algonquin Community College. Twenty-three Forest Technicians graduated from the two-year course in May. 1973 and the Forest Woodworker program graduated its first class.

This fall 40 students are enrolled in the first year of the Technician program, with a record 34 students in second year. In addition, 22 men are taking the Woods Worker course under the watchful of Ted Dupuis. The emphasis here is on practical experience with chain saw, axe and skidder in a variety of forest types yielding products ranging from pulpwood to veneer logs. This year's course is in English and the program will also be offered in French in 1974.

The Algonquin Section prize to the outstanding first year student for 1971-72 was presented to $\mathrm{Mr}$ Dan Drummond by President Walter Giles when he visited the
Section. Mr Drummond was also presented with the D. A. Fraser prize in Denrology and Silviculture at the May graduation ceremonies. The 1972-73 Section prize was won by Mr Darryl Hoelke.

\section{Visiting foresters from Germany}

Alfred Vietinghoff sent the following note on recent visitors from Europe. On October 11 Don George arranged a tour of Algonquin Park for a group led by Prince Hohenlohe from West Germany who represented the private forest owners association of south-west Germany. Don George demonstrated silvicultural operations in tolerant hardwood stands at the Swan Lake experimental station. A flight over Algonquin Park, resplendent in its late fall colours, gave the visitors an impression of the vastness of the forests and therefore of the problems management faces. Don demonstrated the aesthetical aspects of no-cut reserves along lakes and canoe-routes and showed the visitors the many aspects of multiple use management in Algonquin Park.

Here the visitors were on familiar ground. Prince Hohenlohe explained the impact on forest mananagement practices in Germany by demands for recreational activities. Don George was assisted by Rolli Kroeger and Alfred Vietinghoff.

by $\mathrm{K}$. Yeatman

\section{Breeding and Algeria}

Tree breeding in silviculture was the mid-November topic of the Algonquin section, with section members Mark Holst, Kris Morgenstern, Abe Teich and Kit Yeatman outlining some aspects of their work. As part of the session, 32 students in the Forestry Technician course at Algonquin College joined the group for a trip through the provenance experiment plots at the Petawawa Forest Experiment Station.

In December, E. R. Caldwell, manager of the Ottawa Division, Consolidated-Bathurst Limited, gave an illustrated talk on Forestry and Forest Problems in 